\title{
Impaired Suppression of Sympathetic Activity during Fasting in the Gold Thioglucose-treated Mouse
}

\author{
James B. Young and Lewis Landsberg, Department of Medicine and \\ Thorndike Laboratory, Harvard Medical School and Beth Israel Hospital, \\ Boston, Massachusetts 02215
}

\begin{abstract}
A B S T R A C T Sympathetic activity in rats and mice is diminished by fasting and increased by sucrose feeding. The central neural mechanisms coordinating changes in the functional state of sympathetic nerves with changes in dietary intake are unknown, but a role for neurons in the ventromedial hypothalamus (VMH) is suggested by the existence of sympathetic connections within the $\mathrm{VMH}$ and the importance of this region in the regulation of feeding behavior. To investigate the potential role of the $\mathrm{VMH}$ in dietary regulation of sympathetic activity $\left[{ }^{3} \mathrm{H}\right]$ norepinephrine turnover was measured in the hearts of fasted and sucrose-fed mice after treatment with gold thioglucose (AuTG). In control mice, norepinephrine $(\mathrm{NE})$ turnover was $1.60 \pm 0.92$ ng NE/heart per $h$ (95\% confidence limits) after $1 \mathrm{~d}$ of fasting and $4.58 \pm 0.98$ after $3 \mathrm{~d}$ of sucrose feeding, although, in AuTG-treated mice, cardiac NE turnover in fasting was $5.45 \pm 1.56$ and with sucrose feeding, $5.44 \pm 0.76$. Experiments with ganglionic blockade indicate that the absence of dietary effect on NE turnover in AuTG-treated mice reflects a corresponding lack of change in central sympathetic outflow. AuTG administration, therefore, disrupts dietary regulation of sympathetic activity by abolishing the suppression of sympathetic activity that occurs with fasting. This effect of AuTG is unrelated to duration of fasting (up to $3 \mathrm{~d}$ ) and is specific for AuTG because neither treatment with another gold thio compound (gold thiomalate) nor the presence of genetic obesity $(\mathrm{ob} / \mathrm{ob})$ prevented fasting suppression of sympathetic activity. Moreover, AuTG treatment did not impair sympathetic activation by cold exposure $\left(4^{\circ} \mathrm{C}\right)$ nor adrenal medullary stimulation by 2-deoxy-D-glucose. Thus, AuTG treatment selectively impairs dietary regulation of sympathetic activity, possibly by destruction of neurons in the VMH.
\end{abstract}

\section{INTRODUCTION}

Previous studies from our laboratory have demonstrated that, in the rat, changes in sympathetic activity occur

Received for publication 24 July 1979 and in revised form 14 January 1980. with changes in diet: fasting decreases and sucrose feeding increases the functional state of sympathetic nerves in heart, pancreas, and liver (1-3). Although the mechanisms involved in coupling sympathetic activity with changes in diet are unknown, recent evidence suggests that this regulatory process is distinct from adrenal medullary stimulation by hypoglycemia (4). Because the autonomic adjustments to a variety of environmental changes are coordinated within the hypothalamus, alterations in sympathetic activity induced by diet are likely to be governed, in part, by hypothalamic centers. One region of the hypothalamus in particular, the ventromedial hypothalamus (VMH), ${ }^{1}$ has connections with sympathetic centers in the brainstem (5) and participates in the control of feeding behavior (6). Moreover, both electrical activity within the VMH and the rate of release of endogenous catecholamine neurotransmitters from this region are affected by nutritional state and by acute changes in circulating concentrations of insulin and glucose $(7,8)$. In addition, diminished sympathetic activity after electrolytic destruction of the VMH has been inferred from studies of the lipolytic response to various stimuli, including fasting $(9,10)$. These considerations, therefore, suggest a potential role for the $\mathrm{VMH}$ in the regulation of sympathetic activity by diet.

To investigate the possibility that the $\mathrm{VMH}$ is involved in dietary-induced changes in sympathetic activity, the effects of dietary manipulations on the sympathetic nervous system have been studied in mice treated with gold thioglucose (AuTG), a compound that destroys the VMH (11). Sympathetic activity in the hearts of AuTG-treated mice has been assessed by measurement of $\left[{ }^{3} \mathrm{H}\right]$ norepinephrine turnover. This technique depends upon the amine transport system of the axonal membrane to introduce tracer norepinephrine $(\mathrm{NE})$ into the endogenous catecholamine stores within the sympathetic nerve endings (12). After

\footnotetext{
${ }^{1}$ Abbreviations used in this paper: AuTG, gold thioglucose; AuTM, gold thiomalate; 2-DG, 2-deoxy-D-glucose; E, epinephrine; $k$, fractional $\mathrm{NE}$ turnover; $\mathrm{NE}$, norepinephrine; $\mathrm{VMH}$, ventromedial hypothalamus.
} 
equilibration with stored $\mathrm{NE}$, the tracer is released along with endogenous $\mathrm{NE}$ and becomes a valid marker of NE release (13). Quantitation of the rate of disappearance of tracer, expressed as the rate of change of specific activity of $\mathrm{NE}$, permits statistical comparison of sympathetic activity under different experimental conditions. Because release of $\mathrm{NE}$ depends upon sympathetic nerve impulses, more rapid release, reflected in a faster turnover, indicates increased sympathetic activity, and decreased turnover implies decreased sympathetic activity.

The results reported in this paper indicate that, in contrast to dietary modulation of sympathetic activity in the hearts of normal mice, AuTG-treated mice fail to display changes in sympathetic activity in heart with changes in diet; suppression of sympathetic activity by fasting is abolished by AuTG treatment. Sympathoadrenal responses to other, non-nutritional stimuli, such as cold exposure and 2-deoxy-D-glucose (2-DG) administration, are unaffected by AuTG. These results imply an important role for AuTG-sensitive neurons (possibly within the $\mathrm{VMH}$ ) in dietary regulation of sympathetic activity in the mouse.

\section{METHODS}

Female CD-1 mice (20-25 g) obtained from Charles River Breeding Laboratories (Wilmington, Mass.) and C57Bl/6Job obese $(\mathrm{ob} / \mathrm{ob})$ and phenotypically lean $(+/$ ? $)$ mice $(8-10 \mathrm{wk}$ of age) obtained from The Jackson Laboratory (Bar Harbor, Maine) were housed, 10 per cage, in a constant temperature animal room $\left(20^{\circ} \mathrm{C}\right)$ and allowed free access to water and Charles River chow (R-M-H 3000; Agway-Country Foods, Agway Inc., Syracuse, N. Y.), except where noted. While fasting, the animals were permitted free access to a hypotonic electrolyte solution of $\mathrm{Na}+(78 \mathrm{meq} / \mathrm{liter})$ and $\mathrm{K}^{+}(15 \mathrm{meq} / \mathrm{liter})$ and, during sucrose feeding experiments, to a $10 \%$ sucrose solution supplementing the standard lab chow diet.

AuTG-obese mice were developed from the CD-1 strain. AuTG (Sigma Chemical Co., St. Louis, Mo.) was dissolved in isotonic saline and administered intraperitoneally in a dose of $800 \mathrm{mg} / \mathrm{kg}$. Because the effects of AuTG are not uniform throughout a group of treated mice, the subsequent development of obesity was employed as an in vivo estimate of VMH destruction. 6-8 wk after injection, the surviving AuTG-treated $(60-70 \%$ of those injected) and previously uninjected control mice were weighed; those AuTG-treated mice weighing $>4$ SD above the mean weight of the control mice were selected for study. Gold thiomalate (AuTM; Myochrysine, Merck Sharp \& Dohme Div., West Point, Pa.) was dissolved in isotonic saline and injected intraperitoneally in an equivalent gold dosage to AuTG. Animals were studied 7 wk later. Chlorisondamine (Ciba-Geigy Corp., Pharmaceuticals Div., Summit, N. J.) and 2-DG (Sigma Chemical Co.) were dissolved in isotonic saline and injected intraperitoneally in doses of 5 and 500 $\mathrm{mg} / \mathrm{kg}$, respectively.

Colonic temperature was measured with a rectal probe attached to a Yellow Springs telethermometer (Yellow Springs Instruments Co., Yellow Springs, Ohio). The plastic-coated thermistor was dipped in mineral oil and inserted $2 \mathrm{~cm}$ into the colon.

L-[(N)-7, 8- $\left.{ }^{3} \mathrm{H}\right] \mathrm{NE}(30-40 \mathrm{Ci} / \mathrm{mmol}$ sp act; New England Nuclear, Boston, Mass.) was purified before use by column chromatography with alumina as described below. The $\left[{ }^{3} \mathrm{H}\right] \mathrm{NE}$ was diluted to an appropriate concentration with isotonic saline, and injected intraperitoneally at the start of each turnover study. The dose of $\left[{ }^{3} \mathrm{H}\right] \mathrm{NE}$ employed in these studies varied between 250 and $340 \mu \mathrm{Ci} / \mathrm{cm}^{3}(\sim 1-2 \mu \mathrm{g} \mathrm{NE} / \mathrm{kg})^{2}$. The mice were killed at preselected times by cervical dislocation. For each time point in the studies of NE tumover, 4-7 animals were killed from each experimental group, totaling 17-25 animals per turnover line. The organs were rapidly removed, frozen on dry ice, and stored at $-20^{\circ} \mathrm{C}$ for later processing (usually within $2 \mathrm{wk}$ ). The tissues to be analyzed for NE (and for epinephrine $[E]$ where indicated) were homogenized in iced $0.4 \mathrm{~N}$ perchloric acid in a ground glass homogenizer (Kontes Glass Co., Vineland, N. J.) to extract the NE and precipitate the proteins. After volume adjustment, the precipitated protein was removed by low-speed centrifugation.

Isolation of NE (and E) from the perchloric acid extract was by column chromatography with alumina as previously described (15). NE (and E) was absorbed onto the alumina column at $\mathrm{pH} 8.6$ and eluted with $3.0 \mathrm{ml} 0.2 \mathrm{~N}$ acetic acid. The alumina (Woelm neutral; ICN Nutritional Biochemicals, Cleveland, Ohio) had previously been purified according to the method of Anton and Sayre (16). Recovery of added NE or E was usually in excess of $60 \%$ with a variation between columns of $<10 \%$; the results were corrected for recovery as determined in each experiment. Assay of NE (and of $E$ where appropriate) on the alumina eluate was by a modification of the spectrophotofluorometric method of Crout (17). Aliquots of the alumina eluates were counted for $\left[{ }^{3} \mathrm{H}\right] \mathrm{NE}$ by liquid scintillation spectrometry in a Nuclear-Chicago three-channel scintillation counter (Nuclear-Chicago Corp., Des Plaines, Ill.) (15). Efficiency for ${ }^{3} \mathrm{H}$ in this system is $6-8 \%$.

Data are presented as mean \pm SEM, unless otherwise noted. Statistical analyses used the $t$ test for unpaired variables in twotailed tests of the null hypothesis. In the studies of NE tumover, the data were plotted semilogarithmically. The slope of the decline in NE specific activity over time after $\left[{ }^{3} \mathrm{H}\right] \mathrm{NE}$ administration was calculated by the least squares method. The endogenous NE level remained constant over the course of the turnover experiments. NE tumover rates were calculated as the product of the fractional tumover rate and the endogenous NE concentration (13). 95\% confidence intervals were determined for the NE turnover rates as previously described (18). Comparison of fractional tumover rates was made with the $t$ test.

\section{RESULTS}

Effect of fasting and sucrose feeding on NE turnover in control and AuTG-treated mice. In the rat, sympathetic activity is decreased by fasting and increased by sucrose feeding (1-3). As shown in Fig. 1, similar alterations in sympathetic activity in response to changes in diet occur in the mouse. In this experiment fasting began $24 \mathrm{~h}$ and sucrose feeding $72 \mathrm{~h}$ before the injection of $\left[{ }^{3} \mathrm{H}\right] \mathrm{NE}$ and continued for the $24 \mathrm{~h}$ of the study. Halftime of disappearance of $\left[{ }^{3} \mathrm{H}\right] \mathrm{NE}$ increased during fasting from 16.0 to $42.0 \mathrm{~h}$ and decreased during sucrose feeding to $9.1 \mathrm{hr}$. Fasting was associated with a reduction in fractional $\mathrm{NE}$ turnover $(\mathrm{k})$ from $4.34 \pm 1.49$ to $1.65 \pm 0.96 \% / \mathrm{h}(P<0.02)$, and sucrose feeding with an

\footnotetext{
2 This dose of NE borders on the nontracer range when gvien intravenously (13), but after intraperitoneal administration $<0.25 \%$ of the cardiac endogenous NE is represented by labeled NE, well within the accepted limits for a tracer experiment (14).
} 


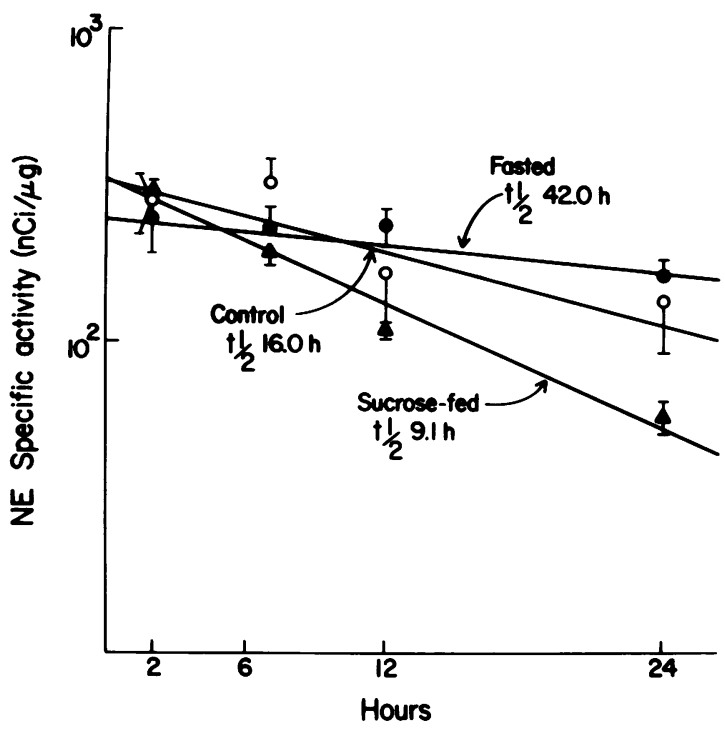

Figure 1 Effects of fasting and sucrose feeding on cardiac NE turnover in control (CD-1) mice. Fasted animals had been without food for $24 \mathrm{~h}$ and sucrose-fed animals had been given supplemental sucrose for $72 \mathrm{~h}$ before the injection of $\left[{ }^{3} \mathrm{H}\right] \mathrm{NE}$ ( $250 \mu \mathrm{Ci} / \mathrm{kg}$ i.p.); they remained on their altered diets for the duration of the experiment. Data are plotted as mean $\pm S E M$ for specific activity of $\mathrm{NE}$ in hearts from four to five animals in each group at each time point. Open circles represent fed, closed circles fasted, and closed triangles sucrose-fed animals. As noted in the text, the slope or $k$ differed significantly between control and fasted animals $(P<0.02)$ and between control and sucrose-fed mice $(P<0.005)$. Calculated $\mathrm{NE}$ turnover rates differed significantly between fasted and sucrose-fed animals.

increase in $\mathrm{k}$ to $7.62 \pm 0.68 \% / \mathrm{h}(P<0.005$ compared with control). Calculated NE turnover rate was lowest with fasting, $0.80 \pm 0.52 \mathrm{ng} \mathrm{NE} /$ heart per h $(95 \%$ confidence limits), and highest with sucrose feeding, $3.06 \pm 0.52 \mathrm{ng} \mathrm{NE} /$ heart per $\mathrm{h}$. Thus, the dietary manipulations of fasting and sucrose feeding produce changes in cardiac sympathetic activity in mice that parallel those seen previously in rats.

The effect of AuTG-treatment on dietary alterations in sympathetic activity was investigated in a similar manner. As shown in Fig. 2, cardiac NE turnover was measured in AuTG-treated mice and in a simultaneously studied group of nontreated, control mice from the original cohort. Fasting began $24 \mathrm{~h}$ and sucrose feeding $72 \mathrm{~h}$ before the start of the turnover experiment and continued for the duration of the study. As in the previous experiment, in control mice $t_{1 / 2}$ was markedly prolonged in fasted animals $(40.2 \mathrm{~h})$ compared with sucrose-fed animals $(11.4 \mathrm{~h})$; $\mathrm{k}$ was less in fasted mice, $1.72 \pm 0.96 \% / \mathrm{h}$, compared with sucrose-fed animals, $6.08 \pm 1.05(P<0.001)$; calculated NE turnover was correspondingly lower with fasting, $1.60 \pm 0.92(95 \%$ confidence limits) vs. $4.58 \pm 0.98 \mathrm{ng} \mathrm{NE} /$ heart per $\mathrm{h}$. In contrast, AuTG-treated mice exhibited no difference in NE
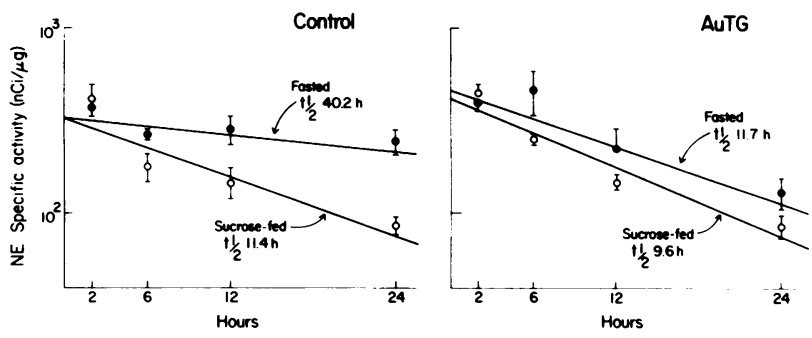

FIGURE 2 Effects of fasting and sucrose feeding on cardiac NE turnover in control and AuTG-treated mice. As in Fig. 1, fasted animals had been without food $24 \mathrm{~h}$ and sucrose-fed animals had received supplemental sucrose for $72 \mathrm{~h}$ before the injection of $\left[{ }^{3} \mathrm{H}\right] \mathrm{NE}(340 \mu \mathrm{Ci} / \mathrm{kg}$ i.p. $)$; they remained on their respective diets for the duration of the experiment. Data are plotted as mean \pm SEM for specific activity of NE in hearts from four to seven animals in each group at each time point. Open circles represent sucrose-fed and closed circles represent fasted animals. $k$ and calculated NE turnover rates were significantly different in fasted and sucrose-fed control mice, but were not different in AuTG-treated mice. NE turnover in fasted and sucrose-fed AuTG-treated mice did not differ from that in sucrose-fed control mice.

turnover between fasted and sucrose-fed animals. The $t_{1 / 2}$ in fasted animals was $11.7 \mathrm{~h}$ and $9.6 \mathrm{~h}$ in sucrose-fed animals; $\mathrm{k}$ rates were similar: $5.92 \pm 1.53 \% / \mathrm{h}$ with fasting and $7.18 \pm 0.73 \% / \mathrm{h}$ (not significantly different) with sucrose feeding. Calculated NE turnover rates were $5.45 \pm 1.56$ ( $95 \%$ confidence limits) in fasted mice and 5.44 $\pm 0.76 \mathrm{ng} \mathrm{NE} / \mathrm{heart}$ per $\mathrm{h}$ in sucrose-fed mice. Thus, in AuTG-treated mice, the differential effects of fasting and sucrose feeding on NE turnover are abolished. Furthermore, the $k$ and calculated NE turnover rate in fasted AuTG-treated mice was significantly greater than in fasted control mice $(P<0.001$ for $\mathrm{k})$, thus implying that the effect of AuTG treatment is to block the suppression of sympathetic activity normally observed in fasting mice.

Because the AuTG-treated mice selected for study were $50 \%$ heavier than the control mice, $24 \mathrm{~h}$ of fasting might not have represented the same metabolic challenge in the two groups. To examine the adequacy of the fasting stimulus, a repeat experiment was performed to evaluate the effect of $48 \mathrm{~h}$ of fasting on NE turnover in AuTG-treated mice. In this study, $24 \mathrm{~h}$ of fasting before the start of the turnover study was compared with ad lib. feeding in control animals, and both 24 and $48 \mathrm{~h}$ of fasting compared with ad lib. feeding in AuTG-treated mice (Fig. 3). In control animals, fasting decreased NE turnover as before; $\mathrm{t}_{1 / 2}$ increased from 6.9 to $12.1 \mathrm{~h}, \mathrm{k}$ decreased from $10.0 \pm 0.6$ to $5.75 \pm 0.65 \% / \mathrm{h}(P<0.001)$, and the calculated $\mathrm{NE}$ turnover rate fell from $14.5 \pm 1.4$ to $9.29 \pm 1.34 \mathrm{ng} \mathrm{NE} / \mathrm{heart}$ per $\mathrm{h}^{3}$ In AuTG-

\footnotetext{
${ }^{3}$ Cardiac NE turnover in control, fasted mice in this experiment was not suppressed to the same extent as observed in Figs. 1 and 2 . The explanation for this difference is unknown.
} 

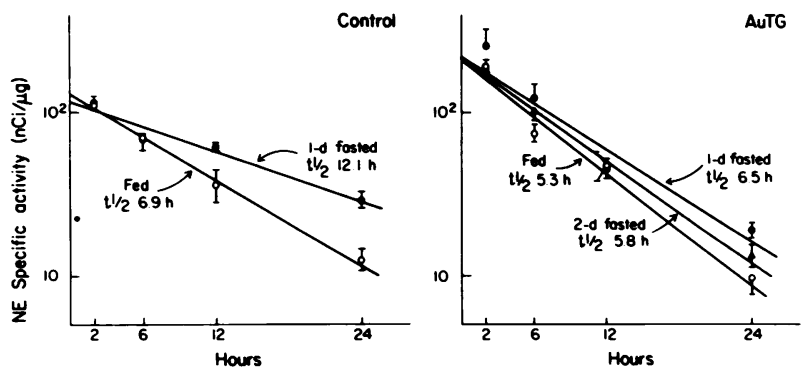

FIGURE 3 Effect of duration of fasting on cardiac NE turnover in control and AuTG-treated mice. Fasted animals had been without food 24 or $48 \mathrm{~h}$ before the injection of $\left[{ }^{3} \mathrm{H}\right] \mathrm{NE}$ $(250 \mu \mathrm{Ci} / \mathrm{kg}$ i.p.) and remained fasting for the duration of the experiment. Data are plotted as mean \pm SEM for specific activity of $\mathrm{NE}$ in hearts from four to five animals in each group at each time point. Open circles represent fed animals, closed circles 1-d fasted mice, and closed triangles 2 -d fasted mice. $k$ and calculated NE turnover rates were significantly different in fed and fasted control mice, but were not different in AuTG-treated mice.

treated mice, fasting, for either 24 or $48 \mathrm{~h}$ before study, failed to produce any change in NE turnover. The $t_{1 / 2}$ in fed, AuTG-treated mice was $5.3 \mathrm{~h}$, in 24 -h fasted mice $6.5 \mathrm{~h}$, and in $48-\mathrm{h}$ fasted animals $5.8 \mathrm{~h}$. $\mathrm{k}$ was $13.2 \pm 1.0$ $\% / \mathrm{h}$ in fed mice, $10.7 \pm 1.2$ in $24-\mathrm{h}$ fasted mice, and $11.9 \pm 0.7$ in 48 - $h$ fasted mice (all differences not statistically significant); calculated NE turnover rates were unchanged as well $(15.2 \pm 1.8 \mathrm{ng} \mathrm{NE} /$ heart per $\mathrm{h}$ in fed animals, $13.9 \pm 2.4 \mathrm{ng} \mathrm{NE} / \mathrm{heart}$ per $\mathrm{h}$ in 24 -h fasted mice, and $14.6 \pm 1.6 \mathrm{ng} \mathrm{NE} /$ heart per $\mathrm{h}$ in 48 -h fasted, AuTG-treated mice). Thus, even after $48 \mathrm{~h}$ of fasting, AuTG-treated mice do not demonstrate the reduction in NE turnover seen after only $24 \mathrm{~h}$ of fasting in control mice.

Effect of ganglionic blockade on NE turnover in fasted and sucrose-fed control and AuTG-treated mice. Evidence that this effect of AuTG treatment to abolish dietary alterations in cardiac $\mathrm{NE}$ turnover represents a change in the regulation of central sympathetic outflow is presented in Fig. 4. Because NE turnover reflects central sympathetic outflow, the imposition of ganglionic blockade produces a greater effect on NE turnover in situations of increased sympathetic activity and, conversely, a lesser effect under conditions of decreased sympathetic activity. In previous studies with fasted and sucrose-fed rats, the introduction of ganglionic blockade with chlorisondamine after administration of tracer $\left[{ }^{3} \mathrm{H}\right] \mathrm{NE}$ led to smaller increases in the retention of tracer in the hearts of fasted animals, and to greater increments in retained tracer in the hearts of sucrose-fed animals, as compared with control, ad lib

Although variations in absolute NE turnover rates in response to dietary manipulations change from time to time, the suppressive effect of fasting is uniformly observed in control rats and mice.

fed animals $(1,2)$; these changes are consistent with a decrease in central sympathetic outflow during fasting and an increase during sucrose feeding. A similar experiment in fasted and sucrose-fed control mice is shown in Fig. 4A. In 1-d fasted control mice, ganglionic blockade produced a minimal $(0.7 \%)$ increase in cardiac $\left[{ }^{3} \mathrm{H}\right] \mathrm{NE}$ compared with saline control over the course of the experiment; after $3 \mathrm{~d}$ of sucrose feeding, the effect of ganglionic blockade was considerably greater, producing an increase in cardiac $\left[{ }^{3} \mathrm{H}\right] \mathrm{NE}$ of $135 \%$. In contrast, ganglionic blockade produced almost equivalent increments in the retention of tracer in heart in fasted ( $2 \mathrm{~d})$ and sucrose-fed ( $3 \mathrm{~d}$ ) AuTG-treated mice: increases of 59 and $75 \%$, respectively (Fig. 4B). Thus, the results of these experiments with ganglionic block-

\section{A. Control}

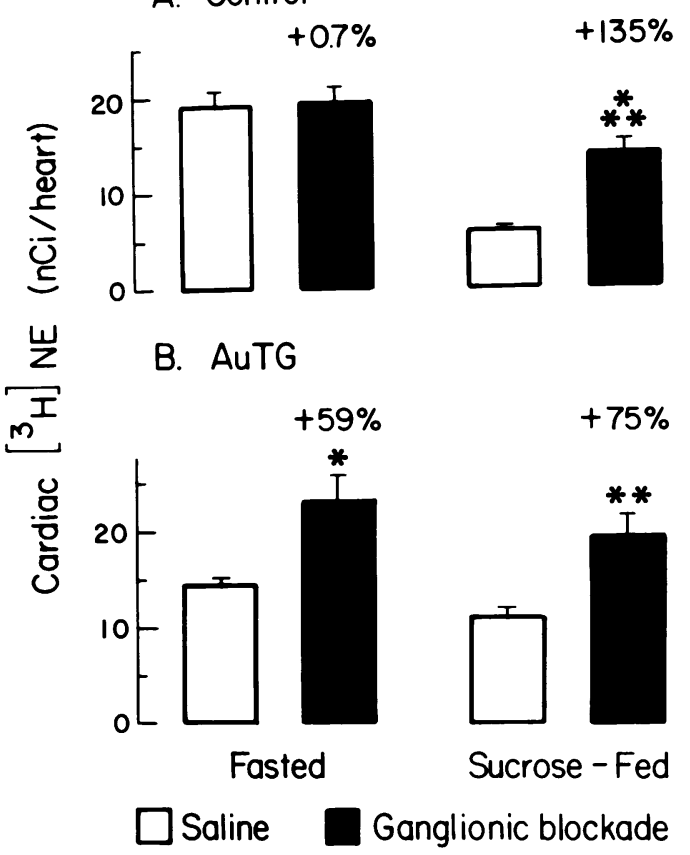

FIGURE 4 Effect of ganglionic blockade on retention of $\left[{ }^{3} \mathrm{H}\right]-$ $\mathrm{NE}$ in the hearts of fasted and sucrose-fed control (A) and AuTG-treated (B) mice. Fasted control mice had been without food $24 \mathrm{~h}$ and sucrose-fed mice had received supplemental sucrose for $72 \mathrm{~h}$ before the injection of $\left[{ }^{3} \mathrm{H}\right] \mathrm{NE}(340 \mu \mathrm{Ci} / \mathrm{kg}$ i.p.); they remained on their respective diets for the duration of the experiment. Fasted AuTG-treated mice had been without food $48 \mathrm{~h}$ before the injection of $\left[{ }^{3} \mathrm{H}\right] \mathrm{NE}(3 \mathrm{IO} \mu \mathrm{Ci} / \mathrm{kg})$, whereas sucrose-fed, AuTG-treated mice received supplemental sucrose for $72 \mathrm{~h}$ before the experiment. After intraperitoneal injection of $\left.{ }^{3} \mathrm{H}\right] \mathrm{NE}$, chlorisondamine (ganglionic blocking agent) or saline was administered intraperitoneally at $40 \mathrm{~min}$ and $6 \mathrm{~h}$. Animals were killed $11 \mathrm{~h}$ after initial injection. Data are presented as mean $\left[{ }^{3} \mathrm{H}\right] \mathrm{NE}$ content $\pm \mathrm{SEM}$ for groups of eight animals each. Open bars represent mean $\left[{ }^{3} \mathrm{H}\right] \mathrm{NE}$ content in hearts of saline-treated animals and closed bars, chlorisondaminetreated animals. Number over bar indicates percentage of increase over saline control. ${ }^{*}, P<0.02 ;{ }^{* *}, P<0.01$; ${ }^{* * *}, P$ $<0.001$ for comparisons between ganglionic blockade and saline treatment. 
ade are consistent with dietary alteration in central sympathetic outflow in control mice, as described before in rats, and with an absence of dietary effect upon central sympathetic outflow in AuTG-treated mice. Furthermore, the enhanced response to ganglionic blockade in fasted AuTG-treated mice, compared with fasted control mice, provides supporting evidence of a lack of suppression of central sympathetic outflow with fasting after AuTG treatment.

Effect of fasting and sucrose feeding on NE turnover in AuTM-treated mice. To examine the possibility that the influence of AuTG administration on dietary changes in sympathetic activity was the result of nonspecific effects of gold, NE turnover was measured in fasted and sucrose-fed mice treated $7 \mathrm{wk}$ previously with an equivalent dose of gold in the form of AuTM. In contrast to AuTG, AuTM does not produce an obesity syndrome (19). The effects of fasting $(24 \mathrm{~h})$ and sucrose feeding $(72 \mathrm{~h}$ ) on cardiac NE turnover in AuTM-treated mice are shown in Fig. 5 . In fasted mice, $t_{1 / 2}$ was longer than in sucrose-fed animals (15.1 and $4.8 \mathrm{~h}$, respectively), $\mathrm{k}$ was lower $(4.58 \pm 1.09$ and $14.4 \pm 1.37 \% / \mathrm{h}$, $P<0.001$ ), and calculated NE turnover rate was reduced $(3.00 \pm 0.92$ and $7.42 \pm 1.46 \mathrm{ng} \mathrm{NE} /$ heart per $\mathrm{h}$, 95\% confidence limits). AuTM administration, thus, did not affect dietary regulation of sympathetic activity, indicating that the lack of fasting suppression of sympathetic activity seen in AuTG-treated mice is not a nonspecific effect of gold administration.

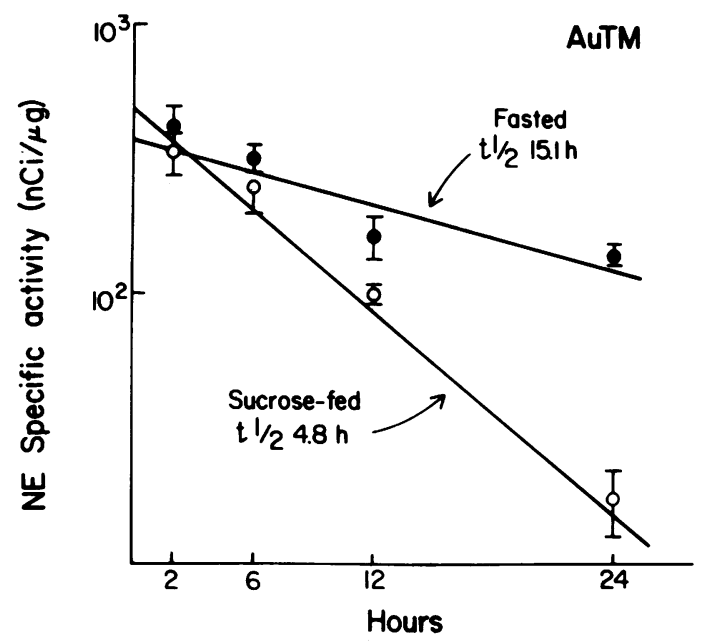

FIGURE 5 Effects of fasting and sucrose feeding on cardiac NE turnover in AuTM-treated mice. Fasted animals had been without food $24 \mathrm{~h}$ and sucrose-fed mice had received supplemental sucrose for $72 \mathrm{~h}$ before the injection of $\left[{ }^{3} \mathrm{H}\right] \mathrm{NE}(250$ $\mu \mathrm{Ci} / \mathrm{kg}$ i.p.); they remained on their respective diets for the duration of the experiment. Data are presented as mean \pm SEM for specific activity of $\mathrm{NE}$ in hearts from four to six animals in each group at each time point. Open circles represent sucrosefed animals and closed circles represent fasted animals. $k$ and calculated $\mathrm{NE}$ turnover rates were significantly different in fasted and sucrose-fed mice.
Effect of fasting and sucrose feeding on NE turnover in control and genetically obese (ob/ob) mice. To investigate whether obesity per se alters dietary regulation of sympathetic activity, the influence of dietary manipulations on NE turnover was assessed in a different mouse model of obesity, the genetically obese ob/ob mouse, and in its phenotypically lean control strain $(+/$ ?). The effects of prior fasting $(24 \mathrm{~h})$ and sucrose feeding (72 h) on cardiac NE turnover in control and ob/ ob mice are shown in Fig. 6. The weights of the ob/ob mice were comparable with those of the AuTG-treated mice in previous experiments, averaging 40-45 g. In both control and ob/ob mice, NE turnover in fasted animals was significantly less than in sucrose-fed mice. The $t_{1 / 2}$ of cardiac NE was prolonged by fasting in both lean controls and ob/ob mice, compared with sucrosefed animals (from 6.4 to $12.4 \mathrm{~h}$ in control mice and from 7.5 to $14.9 \mathrm{~h}$ in the ob/ob mice). $\mathrm{k}$ were slower in fasted than in sucrose-fed mice $(5.64 \pm 1.75 \% / \mathrm{h}$ in fasted controls and $10.9 \pm 1.58 \% / \mathrm{h}$ in sucrose-fed mice $[P$ $<0.05]$, and $4.65 \pm 1.20 \% / \mathrm{h}$ in fasted and $9.23 \pm 1.24 \% / \mathrm{h}$ in sucrose-fed ob/ob mice $[P<0.02])$ and the calculated $\mathrm{NE}$ tumover rates were also different $(4.09 \pm 1.36 \mathrm{ng} \mathrm{NE} /$ heart per $\mathrm{h}[95 \%$ confidence limits] in fasted lean control mice compared with $6.72 \pm 1.21 \mathrm{ng} \mathrm{NE} /$ heart per $\mathrm{h}$ in sucrose-fed controls, $3.35 \pm 0.95$ in fasted mice, and $6.67 \pm 1.23 \mathrm{ng} \mathrm{NE} / \mathrm{heart}$ per $\mathrm{h}$ in sucrose-fed ob/ob mice). Thus, the demonstration of similar changes in cardiac sympathetic activity with fasting and sucrose feeding in control and ob/ob mice indicates that the absence of dietary alteration in cardiac sympathetic activity in AuTGtreated mice cannot be attributed to obesity itself.

Effect of cold exposure on NE turnover in control and AuTG-treated mice. The lack of diet-induced change
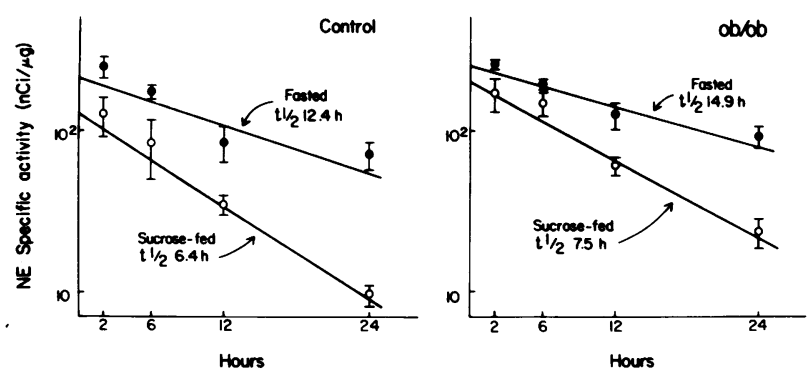

Figure 6 Effects of fasting and sucrose feeding on cardiac NE turnover in genetically obese (ob/ob) and control ( $+/$ ? $)$ mice. Fasted animals had been without food $24 \mathrm{~h}$ and sucrosefed mice had received supplemental sucrose for $72 \mathrm{~h}$ before the injection of $\left[{ }^{3} \mathrm{H}\right] \mathrm{NE}(250 \mu \mathrm{Ci} / \mathrm{kg}$ i.p. $)$; they remained on their respective diets for the duration of the experiment. Data are presented as mean \pm SEM for specific activity of $\mathrm{NE}$ in hearts from four to five animals in each group at each time point. Open circles represent sucrose-fed animals and closed circles represent fasted animals. $k$ and calculated $\mathrm{NE}$ turnover rates were significantly different in fasted and sucrose-fed control mice and in fasted and sucrose-fed ob/ob mice. 
in sympathetic activity in AuTG-treated mice could represent a general defect in sympathetic regulation. To examine the sympathetic nervous system response to a nondietary stimulus, NE turnover was assessed in control and AuTG-treated mice exposed to a cold $\left(4^{\circ} \mathrm{C}\right)$ environment (Fig. 7). In this experiment $\left[{ }^{3} \mathrm{H}\right] \mathrm{NE}$ was injected into control and AuTG-treated mice. $30 \mathrm{~min}$ after injection, half of the mice in each group were placed in the cold. At the end of the experiment the residual tracer $\left[{ }^{3} \mathrm{H}\right] \mathrm{NE}$ was significantly less in the hearts of both cold-exposed control and cold-exposed AuTGtreated mice, compared with the corresponding ambient temperature animals. Because both groups of control and AuTG-treated mice were identical at the beginning of the experiment, the lower tracer content in the hearts of cold-exposed mice at the end of the study reflects increased NE turnover. Thus, activation of the sympathetic nervous system by cold exposure is not affected by prior treatment with AuTG.

Effect of 2-DG administration on adrenal E content in control and AuTG-treated mice. Because glucose is a potential signal in the coupling of sympathetic activity with nutrient intake, the possibility of a AuTGinduced impairment in response to hypoglycemia was investigated using 2-DG, a nonmetabolizable glucose analogue known to stimulate the adrenal medulla by neural mechanisms generally accepted as resembling those activated by hypoglycemia $(20,21)$. After 2 -DG administration, the $\mathrm{E}$ content was measured in adrenal glands of control and AuTG-treated mice removed $3 \mathrm{~h}$ after injection (Table I). The administration of 2-DG

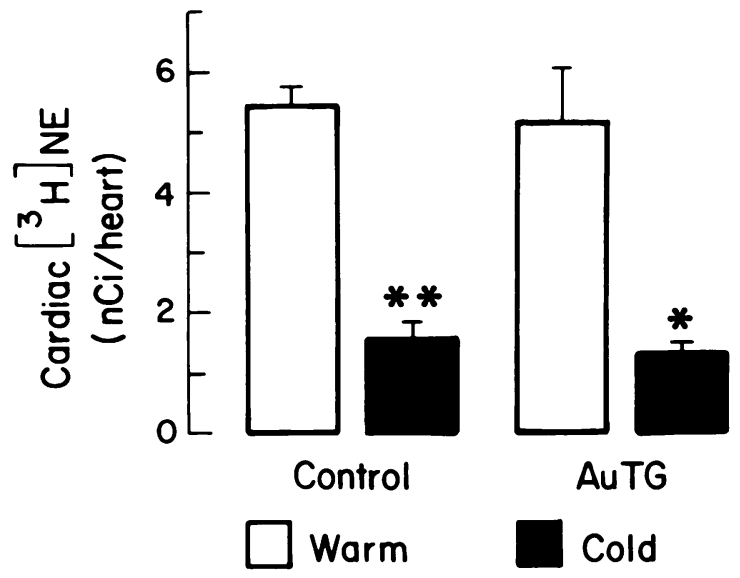

Figure 7 Effect of cold exposure on the retention of $\left[{ }^{3} \mathrm{H}\right] \mathrm{NE}$ in hearts of control and AuTG-treated mice. 30 min after injection of $\left[{ }^{3} \mathrm{H}\right] \mathrm{NE}(260 \mu \mathrm{Ci} / \mathrm{kg}$ i.p. $)$, cold-exposed animals were placed in a cold room $\left(4^{\circ} \mathrm{C}\right)$. Animals were killed $12 \mathrm{~h}$ after injection of tracer NE. Data are presented as mean $\left[{ }^{3} \mathrm{H}\right] \mathrm{NE}$ content \pm SEM for groups of 8-10 animals. Open bars represent mean $\left[{ }^{3} \mathrm{H}\right] \mathrm{NE}$ content in heart of ambient temperature (warm) animals and closed bars, cold-exposed mice. ${ }^{* *}, P<0.005$; ${ }^{* * *}$, $P<0.001$ for comparisons between warm and cold-exposed animals.
TABLE I

Effect of 2-DG on Adrenal $E$ in Control and AuTG-treated Mice

\begin{tabular}{|c|c|c|}
\hline & \multicolumn{2}{|c|}{ Adrenal E } \\
\hline & Saline & 2-DG \\
\hline & \multicolumn{2}{|c|}{ mg/gland } \\
\hline Control & $5.47 \pm 0.59(8)$ & $4.16 \pm 0.21(7)^{*}$ \\
\hline AuTG & $6.10 \pm 0.10(7)$ & $4.10 \pm 0.46(7)$ \\
\hline
\end{tabular}

To mice fed ad lib., 2-DG $(500 \mathrm{mg} / \mathrm{kg})$ was administered i.p., and the animals were killed $3 \mathrm{~h}$ later. Data are presented as mean $\pm S E M$. The numbers in parentheses represent the number of animals in each group.

$* P<0.1,2-D G$ vs. saline.

$\ddagger P<0.001,2-\mathrm{DG}$ vs. saline.

lowered adrenal E $24 \%$ in control mice $(P<0.1)$ and $33 \%$ in AuTG-treated mice $(P<0.001)$. Thus, the adrenal medullary response to $2-D G$ is not inhibited by prior administration of AuTG.

Effect of fasting on colonic temperature in control and AuTG-treated mice. A physiologic concomitant of the lack of suppression of sympathetic activity with fasting after AuTG is provided by measurement of colonic temperature in fed and fasted control and AuTGtreated mice (Table II). Control mice fasted for $1 \mathrm{~d}$ had colonic temperatures $0.5^{\circ} \mathrm{C}$ lower than fed animals $(P<0.001)$. In AuTG-treated mice, colonic temperatures were unaffected by $2 \mathrm{~d}$ of fasting, although basal temperatures in fed AuTG mice were $0.4^{\circ} \mathrm{C}$ below the fed controls $(P<0.01)$. Although the decrease in colonic temperature with fasting in control mice is multifactorial, sympathetic nervous system suppression plays at least a permissive role because sympathetic activation is a major defense against hypothermia in intact, fed animals. The lack of change in colonic temperature in AuTG-treated mice with fasting is consistent with the failure of sympathetic suppression during fasting described above.

TABLE II

Effect of Fasting on Colonic Temperature in Control and AuTG-treated Mice

\begin{tabular}{llc}
\hline & \multicolumn{2}{c}{ Colonic temperature } \\
\cline { 2 - 3 } & \multicolumn{1}{c}{ Ad lib. fed } & \multicolumn{1}{c}{ Fasted* $^{*}$} \\
\hline & & \\
& & \\
Control & $39.0 \pm 0.05(10)$ & $38.5 \pm 0.12(10) \ddagger$ \\
AuTG & $38.6 \pm 0.10(10) \S$ & $38.6 \pm 0.14(10)$ \\
\hline
\end{tabular}

* Control animals were fasted for $1 \mathrm{~d}$ before measurement, AuTG-treated mice for $2 \mathrm{~d}$. The numbers in parentheses represent the number of animals in each group.

$\$ P<0.001$, fasted vs. ad lib. fed control.

$\S P<0.01$, fed control vs. fed AuTG. 


\section{DISCUSSION}

Normal rats and mice consistently suppress sympathetic activity with fasting; this study demonstrates that fasting is without effect on cardiac sympathetic activity in AuTG-treated obese mice. The absence of sympathetic suppression with fasting is not influenced by the duration of the fast (up to $48 \mathrm{~h}$ before the turnover study), and cannot be explained by the nonspecific effects of either gold administration or obesity. The specificity of the AuTG lesion for dietary regulation of sympathetic activity is further emphasized by the normal sympathoadrenal responses of the AuTG-treated obese animal to cold exposure and to 2-DG administration, indicating that AuTG treatment does not result in a general paralysis of sympathoadrenal outflow. Thus, the failure of AuTG-treated mice to suppress cardiac sympathetic activity with fasting appears to be the consequence of specific effects of AuTG on the coupling of sympathetic activity and diet.

As in our previous studies, sympathetic activity has been assessed by measurement of the cardiac NE turnover rate using tracer $\left[{ }^{3} \mathrm{H}\right] \mathrm{NE}(1-3)$. Although this method for measuring sympathetic activity is subject to several theoretical limitations (3), to the extent that they apply, these limitations affect the sensitivity rather than the validity of the technique. Furthermore, there is no reason to assume that the importance of these factors is specifically and uniquely greater in the AuTG-treated mouse than in control or genetically obese mice. The results of the experiments with ganglionic blockade (Fig. 4), moreover, support the use of NE turnover rates to estimate changes in central sympathetic outflow in the AuTG-treated mouse.

The locus of the lesion(s) responsible for the observed impairment in dietary regulation of sympathetic activity in the AuTG-treated mouse is uncertain. AuTG administration destroys a portion of the $\mathrm{VMH}$, the extent of destruction in normal mice being determined by the amount of AuTG injected. Ablation of the VMH in our AuTG-treated mice can be assumed because of the recognized association between AuTG-induced obesity and VMH damage $(22-24)$ and because of previously demonstrated, complete VMH destruction after a AuTG dose $25 \%$ less than that employed in these experiments (25). AuTG, however, produces pathologic lesions in the brain beyond that in the VMH. Other regions of the hypothalamus as well as extrahypothalamic sites within the central nervous system specifically accumulate AuTG and undergo pathologic changes $(26,27)$. One such lesion, that in the dorsal motor nucleus of the vagus, has also been associated with AuTG-induced obesity in mice. ${ }^{4}$ Thus, although the coordination of sym-

${ }^{4}$ Published in the Proceedings of the Sixth International Conference on Physiology of Food and Fluid Intake. 25-28 July 1977, Paris, France. pathetic activity with dietary intake is presumed to occur within the hypothalamus as it does for integration of sympathetic activity with other physiological phenomena, such as temperature regulation, the studies reported here, although consistent with a primary role for the hypothalamus, do not provide definitive localization of the region(s) involved.

A model of dietary regulation of sympathetic activity incorporating the observation of impaired suppression of sympathetic activity with fasting in AuTG-treated mice is presented in Fig. 8. In this model, the brainstem centers that ultimately determine central sympathetic outflow receive descending inhibitory input from more rostral regions in the central nervous system; fasting increases this inhibition and overfeeding sucrose decreases it relative to the ad lib. feeding state. The destruction by AuTG of these higher neurons, possibly within the VMH, removes this inhibitory influence on the brainstem centers. Thus, disinhibition of the brainstem centers by AuTG treatment establishes sympathetic activity at the level usually found in sucrose-fed control animals, regardless of the dietary intake of the lesioned animals. As proposed in Fig. 8, the regulatory organization of the sympathetic nervous system resembles that described by Sherrington (28) for the motor system. In both cases, lower level, tonically active neurons are inhibited by descending impulses from higher centers.

Indirect support for the model in Fig. 8 is available from studies of thermogenic responses to cold exposure. Malnourished human infants and acutely starved, preweanling rats fail to increase oxygen consumption normally upon exposure to environmental temperatures of $20^{\circ}-30^{\circ} \mathrm{C}(29,30)$. In rats, this metabolic restraint of fasting is eliminated by surgical decerebration, indicating the presence of descending inhibitory input in these fasting animals (31). Because the role of sympathetic activation in promoting heat production (oxygen consumption) in the defense against environmental cold is well recognized (32), such data in fasted, coldexposed rats are consistent with the model shown in Fig. 8.

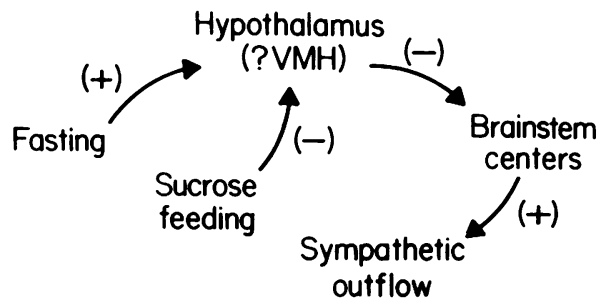

FIGURE 8 Model of dietary regulation of central sympathetic outflow. + , stimulatory influences; -, inhibitory influences. Although this model assumes that the inhibitory influence of dietary restriction arises within the hypothalamus, as indicated in the text, the exact location of these inhibitory neurons is unknown. 
This model of a potential role for the VMH in regulating sympathetic activity in accord with dietary intake is at variance with one recently proposed by Bray and York (33) in which destruction of the VMH is said to reduce sympathetic activity. In the studies upon which their hypothesis is based $(9,10)$, impaired sympathetic activation was inferred from estimates of the lipolytic response to a variety of conditions. The presence of hyperinsulinemia in the VMH-lesioned animals, however, would appear to weaken the connection between lipolysis and sympathetic activity sufficiently so that fat mobilization could not serve as a reliable index of sympathetic activity. On the other hand, the studies reported here, although measuring sympathetic activity directly, did so only in heart. Conceivably, sympathetic outflow to adipose tissue and other areas may be affected differently than heart, although such nonhomogeneity in sympathetic activity after rather gross ablative procedures would seem unlikely.

The connection between impaired dietary regulation of sympathetic activity in AuTG-treated mice and the subsequent development of obesity is unclear. Because catecholamines increase heat production, chronic stimulation of sympathetic activity, if present in organs other than the heart, might be expected to increase the dissipation of ingested calories as heat and thereby limit weight gain. The lack of variation in sympathetic activity otherwise associated with intermittent feeding and fasting might, however, lead to diminished sensitivity to the thermogenic effects of catecholamines. Although adipose tissue from AuTG-obese mice exhibits an impaired lipolytic response to $E$ in vitro (34), further studies are required to define the extent and to explore the implications of this potential alteration in end-organ response to catecholamines in AuTG-treated mice.

\section{ACKNOWLEDGMENTS}

The excellent technical assistance of $\mathrm{M}$. Berardino, S. Gunn, M. Scanlon, S. Fish, and N. Langhans, and the secretarial assistance of Mrs. Edith Cusher are gratefully acknowledged.

This work was supported in part by U. S. Public Health Service grants AM 20378 and RR76.

\section{REFERENCES}

1. Young, J. B., and L. Landsberg. 1977. Suppression of the sympathetic nervous system during fasting. Science (Wash. D. C.). 196: 1473-1475.

2. Young, J. B., and L. Landsberg. 1977. Stimulation of the sympathetic nervous system during sucrose feeding. $\mathrm{Na}$ ture (Lond.). 269: 615-617.

3. Young, J. B., and L. Landsberg. 1979. Effect of diet and cold exposure on norepinephrine turnover in pancreas and liver. Am. J. Physiol. 236: E524-E533.

4. Young, J. B., and L. Landsberg. 1979. Sympathoadrenal activity in fasting rat pregnancy: dissociation of adrenal medullary and sympathetic nervous system responses. $J$. Clin. Invest. 64: 109-116.

5. Ban, T. 1975. Fiber connections in the hypothalamus and some autonomic functions. Pharmacol. Biochem. Behav. 3 (Suppl. 1): 3-13.

6. Lytle, L. D. 1977. Control of eating behavior. In Nutrition and the Brain. R. J. Wurtman and J. J. Wurtman, editors. Raven Press, New York. 2: 1-145.

7. Anand, B. K., G. S. Chhina, K. N. Sharma, S. Dua, and B. Singh. 1964. Activity of single neurons in the hypothalamic feeding centers: effect of glucose.Am.J. Physiol. 207: 1146-1154.

8. Van der Gugten, J., and J. L. Slangen. 1977. Release of endogenous catecholamines from rat hypothalamus in vivo related to feeding and other behaviors. Pharmacol. Biochem. Behav. 7: 211-219.

9. Nishizawa, Y., and G. A. Bray. 1978. Ventromedial hypothalamic lesions and the mobilization of fatty acids. $J$. Clin. Invest. 61: 714-721.

10. Bray, G. A., and Y. Nishizawa. 1978. Ventromedial hypothalamus modulates fat mobilization during fasting. $\mathrm{Na}$ ture (Lond.). 274: 900-902.

11. Liebelt, R. A., and J. H. Perry. 1967. Action of gold thioglucose on the central nervous system. Handb. Physiol. 1 (Sect. 6, Alimentary Canal): 271-285.

12. Whitby, L. G., J. Axelrod, and H. Weil-Malherbe. 1961. The fate of $\mathrm{H}^{3}$ norepinephrine in animals. J. Pharmacol. Exp. Ther. 132: 193-201.

13. Neff, N. H., T. N. Tozer, W. Hammer, E. Costa, and B. B. Brodie. 1968. Application of steady-state kinetics to the uptake and decline of $\mathrm{H}^{3}-\mathrm{NE}$ in the rat heart. $J$. Pharmacol. Exp. Ther. 160: 48-52.

14. Costa, E., D. J. Boullin, W. Hammer, W. Vogel, and B. B. Brodie. 1966. Interactions of drugs with adrenergic neurons. Pharmacol. Rev. 18: 577-597.

15. Landsberg, L., M. B. Berardino, and P. Silva. 1975. Metabolism of ${ }^{3} \mathrm{H}$-L-dopa by the rat gut in vivo: evidence for glucuronide conjugation. Biochem. Pharmacol. 24: 1167-1176.

16. Anton, A. H., and D. F. Sayre. 1962. Study of the factors affecting the aluminum oxide-trihydroxyindole procedure for the analysis of catecholamines. J. Pharmacol. Exp. Ther. 138: 360-375.

17. Crout, J. R. 1961. Catecholamines in urine. Stand. Methods Clin. Chem. 3: 62-80.

18. Taubin, H. L., B. Djahanguiri, and L. Landsberg. 1972. Noradrenaline concentration and turnover in different regions of the gastrointestinal tract of the rat: an approach to the evaluation of sympathetic activity in the gut. Gut.13: $790-795$

19. Marshall, N. B., and J. Mayer. 1954. Energy balance in gold thioglucose obesity. Am. J. Physiol. 178: 271-274.

20. Brown, J. 1962. Effects of 2-deoxyglucose on carbohydrate metabolism: review of the literature and studies in the rat. Metab. Clin. Exp. 11: 1098-1112.

21. Sun, C. L., N. B. Thoa, and I. J. Kopin. 1979. Comparison of the effects of 2-deoxyglucose and immobilization on plasma levels of catecholamines and corticosterone in awake rats. Endocrinology. 105: 306-311.

22. Marshall, N. B., R. J. Barrnett, and J. Mayer. 1955. Hypothalamic lesions in gold thioglucose injected mice. Proc. Soc. Exp. Biol. Med. 90: 240-244.

23. Liebelt, R. A., and J. H. Perry. 1957. Hypothalamic lesions associated with gold thioglucose-induced obesity. Proc. Soc. Exp. Biol. Med. 95: 774-777.

24. Brecher, G., G. L. Laquer, E. P. Cronkite, P. M. Edelman, and I. L. Schwartz. 1965. The brain lesion of gold thioglucose obesity. J. Exp. Med. 121: 395-401.

25. Caffyn, Z. E. Y. 1972. Early vascular changes in the brain of the mouse after injections of goldthioglucose and bipiperidyl mustard. J. Pathol. 106: 49-56. 
26. Debons, A. F., L. Silver, E. P. Cronkite, H. A. Johnson, G. Brecher, D. Tenzer, and I. L. Schwartz. 1962. Localization of gold in mouse brain in relation to gold thioglucose obesity. Am. J. Physiol. 202: 743-750.

27. Perry, J. H., and R. A. Liebelt. 1961. Extra-hypothalamic lesions associated with gold-thioglucose induced obesity. Proc. Soc. Exp. Biol. Med. 106: 55-57.

28. Sherrington, C. S. 1947. The Integrative Action of the Nervous System. Yale University Press, New Haven, Conn. 2nd edition.

29. Brooke, O. B., M. Harris, and C. B. Salvosa. 1973. The response of malnourished babies to cold.J. Physiol. (Lond.). 233: 75-91.

30. Bignall, K. E., F. W. Heggeness, and J. E. Palmer. 1974.
Effects of acute starvation on cold-induced thermogenesis in the preweanling rat. Am. J. Physiol. 227: 1088-1093.

31. Bignall, K. E., F. W. Heggeness, and J. E. Palmer. 1975. Effect of neonatal decerebration on thermogenesis during starvation and cold exposure in the rat. Exp. Neurol. 49: $174-188$

32. Gale, C. C. 1973. Neuroendocrine aspects of thermoregulation. Annu. Rev. Physiol. 35: 391-430.

33. Bray, G. A., and D. A. York. 1979. Hypothalamic and genetic obesity in experimental animals: an autonomic and endocrine hypothesis. Physiol. Rev. 59: 719-809.

34. Soyka, L. F., H. A. Haessler, and J. D. Crawford. 1969. Altered composition and lipolysis of adipose tissue from gold thioglucose obese mice. Am. J. Physiol. 217: 1088-1093. 